دراسات في آثار الوطن العربي 16

\title{
Multi-Analytical Investigation on Roman Wall Paintings: The Case of Tuna El-Gabal Funerary \\ Houses, Middle Egypt
}

\section{Mona Abdel-Ghani ${ }^{\bullet}$}

Fatma S. Madkour ${ }^{\circ}$

\begin{abstract}
A multi analytical study has been undertaken into wall paintings from Tuna El-Gabal funerary houses in El-Minia, Middle Egypt. Tuna El-Gabal is a large site functioned as the necropolis for the ancient Egyptian town of Khnum or Hermopolis. It comprises various remains of Ptolemaic and Roman chapels of which some are in the pure classical style, while others represent a mixture of Pharaonic-Greek style, both of which are covered with wall paintings. In the funerary house under study, the usual wall decorations depicting scenes of daily life or of offering bearers are not found. Instead, geometrical and floral ornaments are executed.
\end{abstract}

The technical investigation of the materials and techniques employed for wall painting of these types of ancient Egyptian funerary houses in Tuna el-Gabal, have not yet been undertaken. In the present study, ground and paint layers as well as paint media were examined using; Fourier transform infrared spectroscopy (FTIR), Optical microscopy (OM), Scanning electron microscopy coupled with energy dispersive X-ray spectroscopy (SEM-EDS), X-ray powder diffraction (XRD) and Raman microscopy in order to characterize materials and techniques employed. Our findings, concerning one of these houses, are discussed and compared with the other findings of previous studies from the same period. Pigments like red and

- Department of Conservation, Faculty of Archaeology, Cairo University, Giza, 12613, Egypt.

• Department of Conservation, Faculty of Fine Arts, Minia, University, Minia, Egypt. 


\section{دراسات في آثار الوطن العربي 16}

goethite, graphite and bone black, calcium carbonate and calcium sulphate are used in the wall paintings as ground layers. The green paint comprised a mixture of Egyptian blue and goethite. Mud bricks were the main substrate on which three types of plaster were used to cover both the walls and the columns.

\section{Introduction}

Tuna El-Gabal is a village and archeological site near the city of Mallawi, in El Menia Governorate in (Middle Egypt). It (used to be) was the necropolis of Khnum (or Hermopolis Magna), from the Middle Kingdom till to the Greco- Roman Period. Six stelae indicating the boundary between Hermopolis and Akhetaten are the oldest monuments found in the site. In the stelae, Akhenaton and his family are depicted making offerings to Aten. From the Greco-Roman Era, there are some catacombs as well as the Tombs of Petosiris and Isidora. Fraser Tombs: Two kilometers south of Tuna El-Gabal, lies another cemetery with the name 'Fraser Tombs' housing rock-cut tombs that date back to the Fourth and the Fifth Dynasties of the Old Kingdom.The Hermopolis Magna site includes several Roman tombs known as funerary houses. They were built by mud brick, covered with white preparation layer and decorated as the same way like the daily life houses. The funerary house number 22 was the one chosen for this study (fig. 1a). It comprises detached buildings with the same structure. Each consists of two chambers, built upon a raised platform. It is approached from the street by a flight of steps leading to a terrace, or balcony which includes two columns that dates back to $2^{\text {nd }}$ or $3^{\text {rd }}$ centuries and the distance between them is about $1.5 \mathrm{~m}$ (fig. 1b). The court between the frontal columns and the house walls have been decorated with ornaments imitation of natural stones such as granite ${ }^{1}$.

The main aim of the research is study the materials used and the technique employed in wall paintings of the funerary house no.

إبراهيم سعد: تونا الجبل, درة في صحر اء دورة ، دار الثقافة للطباعة و النشر ، طنطا، مصر، 


\section{دراسات في آثار الوطن العربي 16}

22 at the necropolis in Tuna El-Gabal (fig. 2). Fourier transform infrared spectroscopy (FTIR), Optical microscopy (OM), Scanning electron microscopy coupled with energy dispersive $\mathrm{X}$ ray spectroscopy (SEM-EDS), X-ray powder diffraction (XRD) and Raman microscopy were used in order to characterize the materials and the techniques employed.

\section{Analytical methods}

\subsection{Sampling}

Different samples of painted surfaces (red brown, yellow, green, black, and creamy) and other samples from plaster layers taken from both the external façade and the two columns from the terrace were examined. Furthermore a sample from mud brick walls was also studied by different analytical methods (table 1).

\subsection{X-ray powder diffraction (XRD)}

Analysis by X-ray powder diffraction (XRD) was performed with an X'Pert PRO PANalytical diffractometer equipped with conventional X-ray tube $(\mathrm{Cu}-\mathrm{K} \alpha)$ radiation $(\mathrm{k}=1.5406 \AA)$ with power condition $40 \mathrm{kV}$ and $25 \mathrm{~mA}$. The XRD patterns were measured in the range of 4 to $70^{\circ}(2 \theta)$ with the step size of $0.02^{\circ}$ and $30 \mathrm{~s}$ counting per step at room temperature $\left(25^{\circ} \mathrm{C}\right)$.

\subsection{Fourier transform infrared Spectroscopy (FTIR)}

FTIR spectra were obtained using a Bruker FTIR spectrometer, model VERTEX 70 equipped with ATR. The IR spectra, in absorbance mode, were obtained from the specimens, using an aperture of $20-100 \mu \mathrm{m}$, in the spectral region 400 to $4000 \mathrm{~cm}^{-1}$. The resolution was $4 \mathrm{~cm}^{-1}$ and the number of co-added scans was 64 for each spectrum.

\subsection{Scanning electron microscopy (SEM/EDS)}

The SEM-EDX analysis were performed with JEOL 5410 scanning electron microscope equipped with an Oxford (England) EDX microanalysis sys-tem $(25 \mathrm{kV}, 0.28 \mathrm{nA}, \sim 1 \mu \mathrm{m}$ beam diameter, $60 \mathrm{~s}$ counting time). Elemental analysis was obtained using the Oxford INCA-Energy software. 
دراسات في آثار الوطن العربي 16

\subsection{Raman microscopy}

A Senterra Raman spectrometer (Bruker) was used in the current work, consisting of a confocal Raman microscope $(20 \times$ objective lens) with a spectral footp rint of about $4 \mu \mathrm{m}, 4 \mathrm{~cm}^{-1}$ spectral resolution and operating with a laser wavelength of $785 \mathrm{~nm}$.

Raman spectra were subjected to baseline correction and smoothed. All compounds were identified by comparing their characteristic vibrational spectra with those in published databases $^{2,3}$.

\section{Results and discussion}

Visual inspections and optical microscopic investigations of the layered structure of the painted plasters suggested that two distinct layers of white plaster were applied on walls and columns made of unbaked mud brick (fig. 2, a1). The paint layers were applied thinly using fresco technique in which the paint is applied directly to wet lime plaster. As the plaster dries, the particles of pigment are pulled into the surface of the plaster and locked in place by particles of $\mathrm{Ca}(\mathrm{OH})_{2}$. Calcium hydroxide reacts with carbon dioxide $\left(\mathrm{CO}_{2}\right)$ and converts to calcium carbonate $\mathrm{CaCO}_{3}{ }^{4}$. Upon drying, the colour chroma intensifies as a significant amount of shrinkage takes place in the surface, causing the pigments to be drawn closer together over a smaller surface area ${ }^{5}$.

2 Burgio, L., Clark, R J H (2001). "Library of FT-Raman spectra of pigments, minerals, pigment media and varnishes, and supplement to library of Raman spectra of pigments with visible excitation." Spectrochimica Acta A 57: 1491-1521.

${ }^{3}$ Bell, I. M., R. J. H. Clark, et al. (1997). "Raman spectroscopic library of natural and synthetic pigments (pre-similar to 1850 AD)." Spectrochimica Acta Part a-Molecular and Biomolecular Spectroscopy 53(12): 2159-2179.

${ }^{4}$ Pavlidou, E., Arapi, M., Zorba, T., Anastasiou, M., Civici, N., Stamati, F.,

Paraskevopoulos, K. M "Onoufrios, the famous XVI's century iconographer, creator of the

"Berati School": studying the technique and materials used in wall paintings of inscribed churches." Applied Physics A (2006) 83: 709-717.

${ }^{5}$ Rapp G. Archaeomineralogy. Herrmann B, Wagner, G.A, editor. Berlin Heidelberg Springer-Verlag 2009, p. 204. 


\section{دراسات في آثار الوطن العربي 16}

\subsection{The substrate and the decorated plaster}

The XRD results are listed in table 2. The XRD pattern of the mud brick walls revealed quartz as major constituents in addition to alumino-silicate minerals, namely orthoclase $\left(\mathrm{KAlSi}_{3} \mathrm{O}_{8}\right)$, plagioclase (albite $\mathrm{NaAlSi}_{3} \mathrm{O}_{8}$ ) and potassium feldspar (microcline $\left.\mathrm{KAlSi}_{3} \mathrm{O}_{8}\right)$. Gypsum $\left(\mathrm{CaSO}_{4} \cdot 2 \mathrm{H}_{2} \mathrm{O}\right)$ was also identified in the mud brick sample. Plant-fiber tamper (straw) is also found in the mud brick which normally added to act as a binder, to control shrinkage and to prevent cracking. It does not give added strength to brick, but serves to make the brick dry and shrink as one unit ${ }^{4}$. The FTIR spectrum of the mud brick substrate shows the characteristic bands features of Kaolin at $3694,3619,1029,513$ and $458 \mathrm{~cm}^{-1}$ and quartz at $780,691 \mathrm{~cm}^{-1}$ (figure 3). Mud-brick continued to be used for the lining for burial chambers and for roof vaulting for the subterranean portions in tombs of the New Kingdom and in the Ptolemaic, Roman, and even in Coptic tombs ${ }^{6}$.

The white preparation layer of the wall paintings comprises two distinct layers; the fine (fig. 2, a3 \& fig, 4, a) and coarse plaster (fig. 2, a2 \& fig, 4, a). The fine plaster comprised calcite as the main calcite $\left(\mathrm{CaCO}_{3}\right)$ with different proportion of quartz $\left(\mathrm{SiO}_{2}\right)$.

The XRD pattern of the fine layer confirmed that the main constituents were calcite and quartz with a small amount of clay, namely; orthoclase and microcline. This result is consistent with a lime plaster, which is constituted by lime which becomes calcite after hardening and small grains of quartz and traces of clay minerals (figure 5 ).

In the FTIR spectra of the plaster, the existence of calcite is identified from the bands at $1431,875,713 \mathrm{~cm}^{-1}$ due to the $\mathrm{CO}_{2}{ }^{-3}$ group of calcite. The silicates or alumino-silicates materials are revealed the most characteristic bands of the $\mathrm{SiO}_{4}$ tetrahedra at

\footnotetext{
${ }^{6}$ Abo El-Yamin, A., Mahmoud, H. M., and Brania, A., Analytical study of Coptic wall paintings in Egypt, El-Bagawat necropolis, Kharga Oasis: a case study, Periodico di Mineralogia (2013), 82, 1, 25-40.
} 
دراسات في آثار الوطن العربي 16

1082, 780, and $458 \mathrm{~cm}^{-1} 7$ (figure 6a). The EDX analysis of the plaster layers gave the same ingredients, with addition to a small proportion of haematite $\alpha-\mathrm{Fe}_{2} \mathrm{O}_{3}$.

The coarse plaster layer and the plaster covered the two columns in the terrace of the house, were also examined. The XRD patterns indicated that the main constituents of these plasters were gypsum $\left(\mathrm{CaSO}_{4} \cdot 2 \mathrm{H}_{2} \mathrm{O}\right)$ in addition to calcite $\left(\mathrm{CaCO}_{3}\right)$ and quartz $\left(\mathrm{SiO}_{4}\right)$. The FTIR analysis gave the same results with the characteristic bands of gypsum at 3543, 3404, 1623 and $1120 \mathrm{~cm}^{-}$ ${ }^{1}$ which are attributed to the bending and stretching modes of the $\mathrm{SO}_{4}^{-2}$ group and the bands of calcite ${ }^{7}$ at $1438,875,780$ and 670 $\mathrm{cm}^{-1}$ (figure 6b).

The only difference between the coarse plaster of the wall paintings and the plaster of the two columns is the presence of plant-fiber temper, which was added to the coarse plaster for revealing more strength ${ }^{8}$.

The organic material found in all the plaster layers was studied. The FTIR spectra include methylene group absorbencies at 2852 and $2923 \mathrm{~cm}^{-1}$, and a broad peak between $3000-3750 \mathrm{~cm}^{-1}$ indicating hydroxyl and amide groups. The revealed characteristics suggest that the organic material in the plaster layers is animal glue ${ }^{9}$ (fig.6, a \& b).

\subsection{The paint layers}

Analytical investigations carried out on the painting layers using optical microscopy, Raman microscopy, SEM-EDX and XRD analysis of pigment samples determined a limited variety of

7 Pavlidou, E., Arapi, M., Zorba, T., Anastasiou, M., Civici, N., Stamati, F., Paraskevopoulos, K. M "Onoufrios, the famous XVI's century iconographer, creator of the "Berati School": studying the technique and materials used in wall paintings of inscribed churches." Applied Physics A (2006) 83: 709-717.

8 Maritan, L., Nodari, L., Mazzoli, C., Milano, A., Russo, U. Influence of firing condition on ceramic products: Experimental study on clay rich in organic matter. Applied Clay Science (2006) 31, 1-15.

9 Zorba, T., Pavlidou, E., Stanojlovic, M., Bikiaris, D., Paraskevopoulos, K. M., Nikolic, V., Nikolic, P. M. "Technique and palette of XIIIth century painting in the monastery of Mileseva." Applied Physics A (2006) 83: 719-725. 


\section{دراسات في آثار الوطن العربي 16}

pigments. The pigment palette was poor and mostly based on clay minerals with different amounts of iron oxides. Calcite was detected in most samples, corresponding to the composition of the white preparation layer of the wall paintings. The presence of calcite in most samples showed that the paint layer is very thin ${ }^{10}$.

\subsubsection{Red, brown, creamy and yellow paint areas}

Red, brown, yellow and creamy colours found on the painted surfaces of our samples (fig 7, a-c) are mainly attributed to Ferich mineral red ochre. The yellow and creamy paint areas were found to contain no yellow ochre pigment, but red ochre with appreciable amount of calcite. Red ochre $\left(\mathrm{Fe}_{2} \mathrm{O}_{3}+\mathrm{H}_{2} \mathrm{O}+\right.$ clay + silica) is one of the principal red pigments in Egypt in addition to the red iron oxide (hematite) ${ }^{11}$.

The EDX analysis on red-coloured areas of sample revealed concentrations of $\mathrm{Fe}_{2} \mathrm{O}_{3} 5.0 \%$ while other paint areas contain less concentration in addition to aluminium (Al), silicon ( $\mathrm{Si}$ ) and calcite $(\mathrm{Ca})$. The Raman spectra for all samples comprise red ochre $\left(\mathrm{Fe}_{2} \mathrm{O}_{3}\right)$, the main red pigment identified, with its characteristic Raman bands at 225, 294, 413, 403 and $605 \mathrm{~cm}^{-1}$ in addition to calcite with its Raman band at $1088 \mathrm{~cm}^{-1}$ and gypsum at $1007 \mathrm{~cm}^{-1}$ (Fig. 8).

The FTIR spectrum of red and yellow paint surfaces showed a carbonyl stretching vibration absorption band at $1320 \mathrm{~cm}^{-1}$. This suggest to be weddellite (calcium oxalate dihydrate: $\mathrm{CaC}_{2} \mathrm{O}_{4} \cdot 2 \mathrm{H}_{2} \mathrm{O}$ ). Calcium oxalate is resulting from the presence of

10 Olivares, M., Castro, K., Corchón, M. S., Gárate, D., Murelaga, X., Sarmiento, A., Etxebarria, N. Non-invasive portable instrumentation to study Palaeolithic rock paintings: the case of La Peña Cave in San Roman de Candamo (Asturias, Spain). Journal of Archaeological Science (2013) 40, 1354-1360.

${ }^{11}$ Calza, C., Anjos, M. J., de Souza, S. M. F. M., Brancaglion, A., Lopes, R. T. "X-ray microfluorescence analysis of pigments in decorative paintings from the sarcophagus cartonnage of an Egyptian." Nuclear Inst. and Methods in Physics Research, B (2007) 263(1), 249-252. 


\section{دراسات في آثار الوطن العربي 16}

metabolism activity of lichens, which by the excretion of oxalic acid convert calcite to calcium oxalate ${ }^{12}$.

\subsubsection{Black paint areas}

The dark black hue on the wall paintings (fig. 7, d) is mainly attributed to graphite (C) and in some instances to bone black. The former was revealed in the Raman spectrum with its characteristic bands at 1315 and $1579 \mathrm{~cm}^{-1}$. The band at $1315 \mathrm{~cm}^{-}$ ${ }^{1}$ arises from stretching vibrations in the planar graphite structure and the band at $1558 \mathrm{~cm}^{-1}$ is a result of defects of graphite structure and the presence of heteroatoms ${ }^{13}$. Graphite was found to be admixed with red ochre to reveal dark brown shade. The latter pigment, bone black, was identified in the black paint areas where the phosphate group $\left(\mathrm{PO}_{4}{ }^{-2}\right)$ is present at 1122 and 1030 $\mathrm{cm}^{-1}$ as shown in the FTIR spectrum (fig. 9). Bone black was also identified by the EDX analysis, where the concentration of phosphate group was found to be $1.8 \%$ (fig. 10)

\subsubsection{Green paint areas}

The optical microscope image of the green paint area showed a yellow matrix with blue crystals embedded within this matrix. The XRD analysis suggested that the two pigments were goethite $\mathrm{FeOOH}$ as a predominant pigment and Egyptian blue (cuprorivaite, $\mathrm{CaCuSi}_{4} \mathrm{O}_{10}$ ) (fig. 11). Quartz was also present in appreciable amount. The Raman spectrum gave the characteristic features of Egyptian blue at 124, 228, 380, 437, 476, 572, 983, 1017 and 1085

$\mathrm{cm}^{-1}$ and goethite bands at 300, 390, 550 and $685 \mathrm{~cm}^{-1}$. Egyptian blue is the earliest synthetic blue pigment of the rare natural pigment cuprorivaite. It consists of a synthetic copper tetrasilicate compound $\mathrm{CaCuSi}_{4} \mathrm{O}_{10}$, residual silica (quartz or/and

${ }^{12}$ Lluveras, A., Torrents, A., Giráldez, P., Vendrell-Saz, M. "Evidence for the use of Egyptian blue in an $11^{\text {th }}$ century mural alterpiece by SEM-EDS, FTIR and SRXRD (church of Sant pere, terrassa, spain)." Archaeometry (2010) 52(2): 308-319.

${ }^{13}$ Gomes, H., Rosina, P., Holakooei, P., Solomon, T., Vaccaro, C. "Identification of pigments used in rock art paintings in Gode Roriso-Ethiopia using Micro-Raman Spectroscopy " Journal of Archaeological Science (2013) 40: 4073-4082. 


\section{دراسات في آثار الوطن العربي 16}

tridymite) an amorphous silica-rich glass phase and in some cases, parawollastonite $\left(\mathrm{CaSiO}_{3}\right)^{14}$. The Earliest known uses of Egyptian blue are from the $4^{\text {th }}$ Dynasty $(2723-2563$ BC) in Egypt, in a sarcophagus in the Egyptian museum, Cairo, and on painted limestone sculptures. Egyptian blue is made by mixing together sources of silica (mostly sand), lime (calcite or limestone), copper compounds (coppear ores or bronze waste) with the addition of flux (any alkali such as potassium carbonate $\left(\mathrm{K}_{2} \mathrm{CO}_{3}\right)^{15}$, natron (a natural sodium sesquicarbonate $\left(\mathrm{Na}_{2} \mathrm{CO}_{3} \cdot \mathrm{NaHCO}_{3} \cdot 2 \mathrm{H}_{2} \mathrm{O}\right){ }^{16}$ in a ratio of 5 quartz : 2 lime : 2 copper : 1 soda. The mixture would then be ground to a fine powder $^{17}$.

\section{Conclusions}

A multi analytical study has been undertaken into wall paintings from Tuna El-Gabal funerary houses in El-Minia, Middle Egypt. Tuna El-Gabal is a large site functioned as the necropolis for the ancient Egyptian town of Khnum or Hermopolis. In the funerary house under study is number 22 .

The technical investigation of the materials and techniques employed for wall painting of one of ancient Egyptian funerary houses in Tuna El-Gabal, have been undertaken. The mud brick substrate, white preparation layers and painted surfaces as well as paint media were examined. The analytical instruments used were Fourier transform infrared spectroscopy (FTIR), Optical microscopy (OM), Scanning electron microscopy coupled with energy dispersive X-ray spectroscopy (SEM-EDS), X-ray powder diffraction (XRD) and Raman microscopy.

\footnotetext{
${ }^{14}$ Pages-Camagna, S., Colinart, S. The Egyptian green pigment: its manufacturing process and links to Egyptian blue. Archaeometry, (2003), 45(4), 637-658.

${ }^{15}$ Daniels, V., Stacey, R., Middleton, A. The blacking of paint containing Egyptian blue. Studies in Conservation, (2004), 49, 217-230.

${ }^{16}$ Davison, S. Conservation and Restoration of Glass. Great Britain, ButterworthHeinemann (2006), 74.

${ }^{17}$ Eastaugh, N., Walsh, V., Chaplin, T., Siddal, R. The Pigment Compendium: A Dictionary of Historical Pigments. Oxford: Elsevier, Butterworth-Heinmann, (2004), p.148.
} 


\section{دراسات في آثار الوطن العربي 16}

The main substrate, on which the painted surfaces were applies, was found to be mud bricks. The white preparation layers of the wall paintings comprise two layers with different composition of which the fine layer was made of calcite and the coarse layer was made of gypsum. The Pigments identified were red ochre, goethite, graphite and bone black. Calcium carbonate and calcium sulphate are used in the wall paintings as ground layers and as fillers. The green paint comprised a mixture of Egyptian blue and goethite. Fresco technique was the one used for applying the pictorial layer in which no paint medium was used. 
دراسات في آثار الوطن العربي 16

\section{Table (1): Description of the studied samples}

$\begin{array}{lll}\text { No. } & \text { Type of sample } & \text { Description } \\ 1 & \text { Fine ground } & \text { Fragment of plaster covered the walls } \\ 2 & \text { Coarse ground } & \text { Fragment of plaster covered the walls } \\ 3 & \text { Coarse ground } & \text { Fragment of plaster covered the exterior columns } \\ 4 & \text { Red brown } & \text { Painted fragment } \\ 5 & \text { Yellow ocher } & \text { Painted fragment } \\ 6 & \text { Light green } & \text { Painted fragment } \\ 7 & \text { Black } & \text { Painted fragment } \\ 8 & \text { Creamy } & \text { Painted fragment } \\ 9 & \text { Mud brick support } & \text { Fragment }\end{array}$

Table (2): XRD results of substrate, plaster and paint layers

Kind of Sample Identified Minerals

\begin{tabular}{|c|c|c|c|}
\hline & Major & Minor & traces \\
\hline Fine ground & Calcite $\mathrm{CaCO}_{3}$ & Quartz $\mathrm{SiO}_{2}$ & Gypsum $\mathrm{CaSO}_{4} \cdot 2 \mathrm{H}_{2} \mathrm{O}$ \\
\hline Coarse ground & $\begin{array}{l}\text { Gypsum } \mathrm{CaSO}_{4} \cdot 2 \mathrm{H}_{2} \mathrm{O} \\
\text { Calcite } \mathrm{CaCO}_{3}\end{array}$ & - & $\begin{array}{l}\text { Quartz } \mathrm{SiO}_{2} \\
\text { Hematite } \mathrm{Fe}_{2} \mathrm{O}_{3}\end{array}$ \\
\hline Red brown & Calcite $\mathrm{CaCO}_{3}$ & Quartz $\mathrm{SiO}_{2}$ & $\begin{array}{l}\text { Hematite } \mathrm{Fe}_{2} \mathrm{O}_{3} \\
\text { Gypsum } \mathrm{CaSO}_{4} \cdot 2 \mathrm{H}_{2} \mathrm{O}\end{array}$ \\
\hline Yellow Ochre & Calcite $\mathrm{CaCO}_{3}$ & & $\begin{array}{l}\text { Hematite } \mathrm{Fe}_{2} \mathrm{O}_{3} \\
\text { Quartz } \mathrm{SiO}_{2}\end{array}$ \\
\hline Light green & $\begin{array}{l}\text { Goethite }(\mathrm{FeOOH}) \\
\text { cuprorivaite, } \mathrm{CaCuSi}_{4} \mathrm{O}_{10}\end{array}$ & Quartz $\mathrm{SiO}_{2}$ & \\
\hline Black & Calcite $\mathrm{CaCO}_{3}$ & & $\begin{array}{l}\text { Gypsum } \mathrm{CaSO}_{4} \cdot 2 \mathrm{H}_{2} \mathrm{O} \\
\text { Quartz } \mathrm{SiO}_{2}\end{array}$ \\
\hline Creamy & Calcite $\mathrm{CaCO}_{3}$ & Quartz $\mathrm{SiO}_{2}$ & $\begin{array}{l}\text { Gypsum } \mathrm{CaSO}_{4} \cdot 2 \mathrm{H}_{2} \mathrm{O} \\
\text { Hematite } \mathrm{Fe}_{2} \mathrm{O}_{3}\end{array}$ \\
\hline Mud brick & Quartz $\mathrm{SiO}_{2}$ & & $\begin{array}{l}\text { Albite, microcline orth } \\
\text { gypsum } \mathrm{CaSO}_{4} \cdot 2 \mathrm{H}_{2} \mathrm{O}\end{array}$ \\
\hline
\end{tabular}


دراسات في آثار الوطن العربي 16
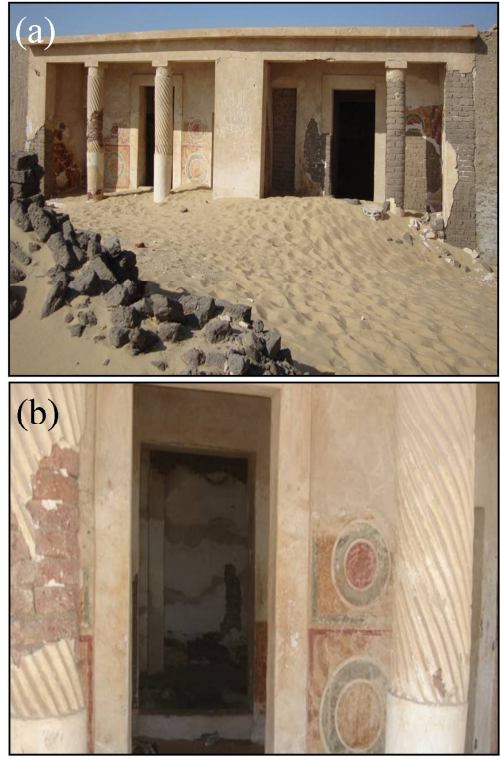

Figure 1. the exterior of the workers' funerary house No.22: (a) full view, (b) partial view
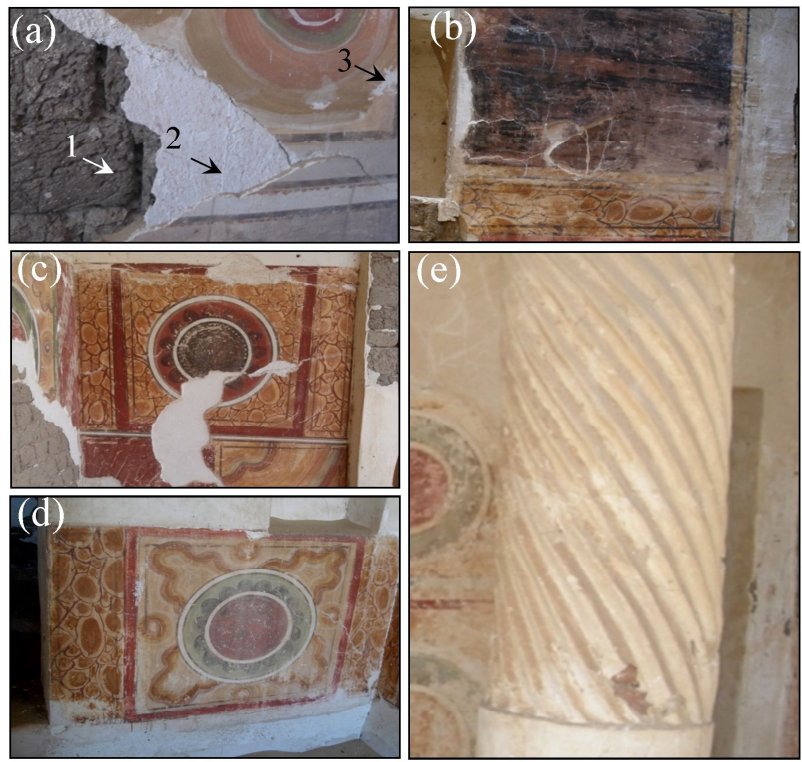

Figure 2. the decorative surfaces of the workers' funerary house No.22: (a) the layered structure of the painted surfaces (1) the mud brick substrate (2) the coarse plaster (3) the fine plaster, $(b, c, d)$ the sampled areas from wall paintings, (e) the column of the terrace

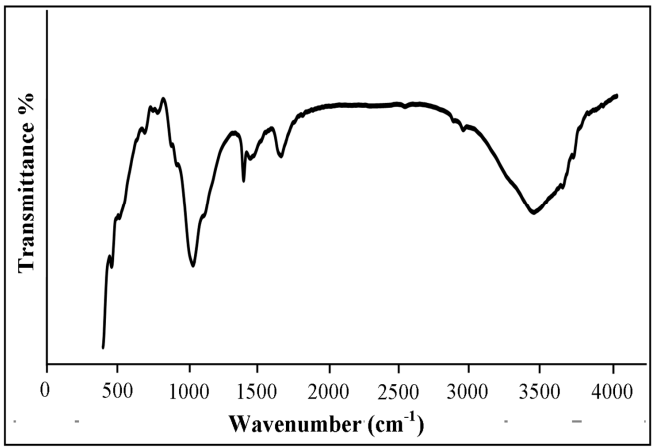

Figure 3. the FTIR spectra of the mud brick substrate

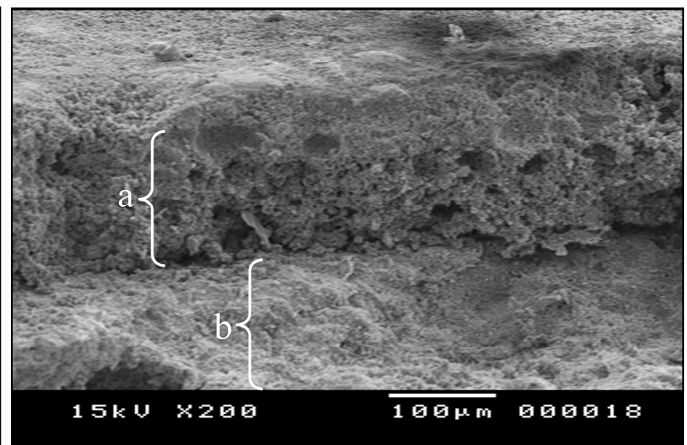

Figure 4. the SEM macro photograph showing the fine (a) and the coarse (b) plaster layer of the white preparation layer of wall paintings 


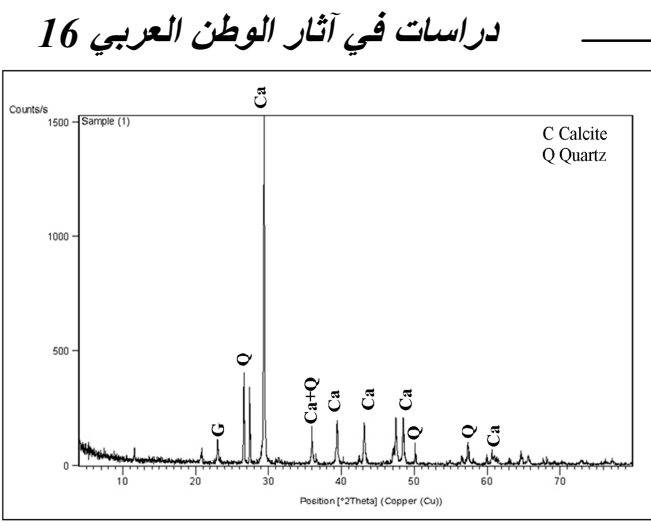

Figure 5. the XRD pattern of the fine plaster
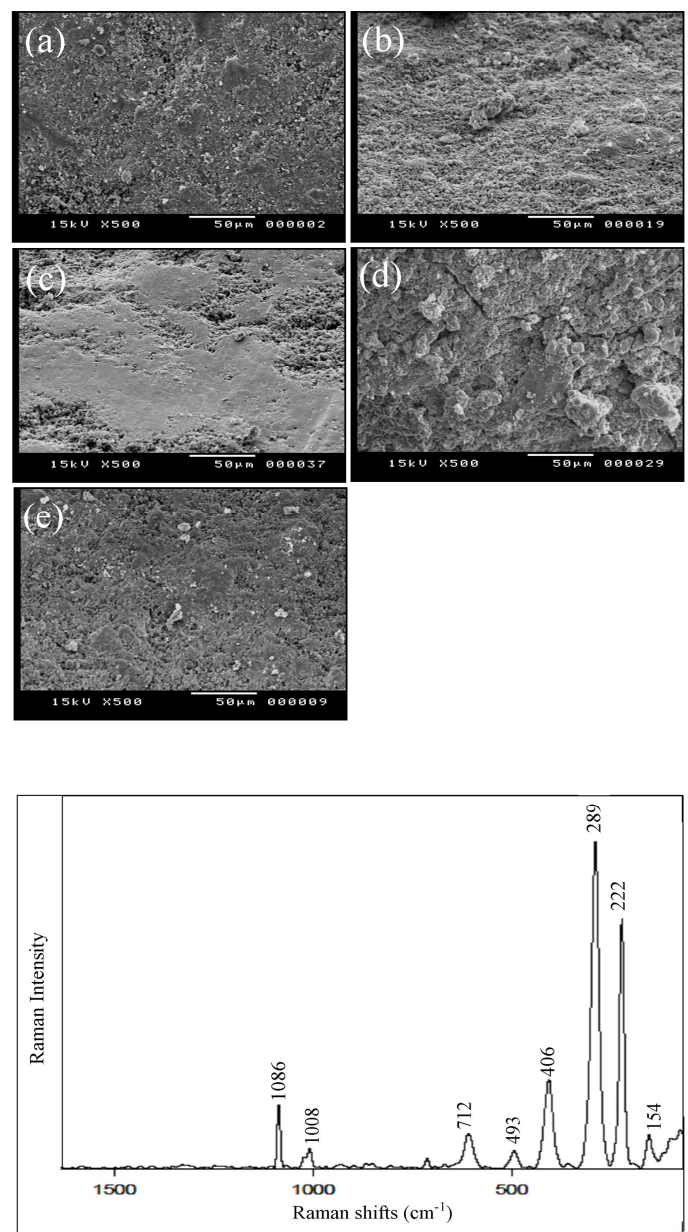

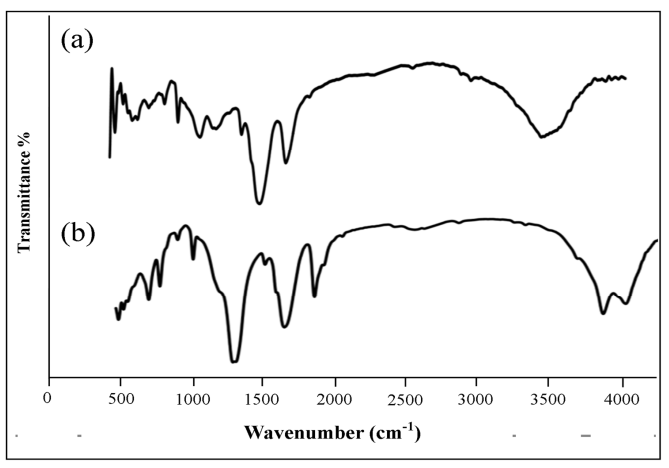

Figure 6. the FTIR spectra of (1) the plaster layer of the wall paintings, (b) the plaster layer of the column

Figure 7. the SEM macroscopic images of painted surfaces; (a) red paint, (b) yellow paint, (c) creamy paint, (d) black paint, (e) green paint

Figure 8. the Raman spectrum of the red paint area 
دراسات في آثار الوطن العربي 16

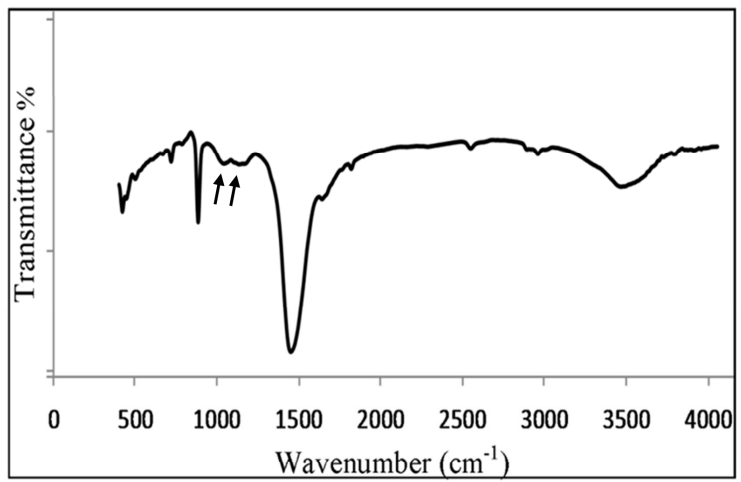

Figure 9. the FTIR spectrum of the black paint area showing the phosphate group (arrowed)

Figure 10. the EDX spectrum of the black paint area (phosphorous is arrowed)
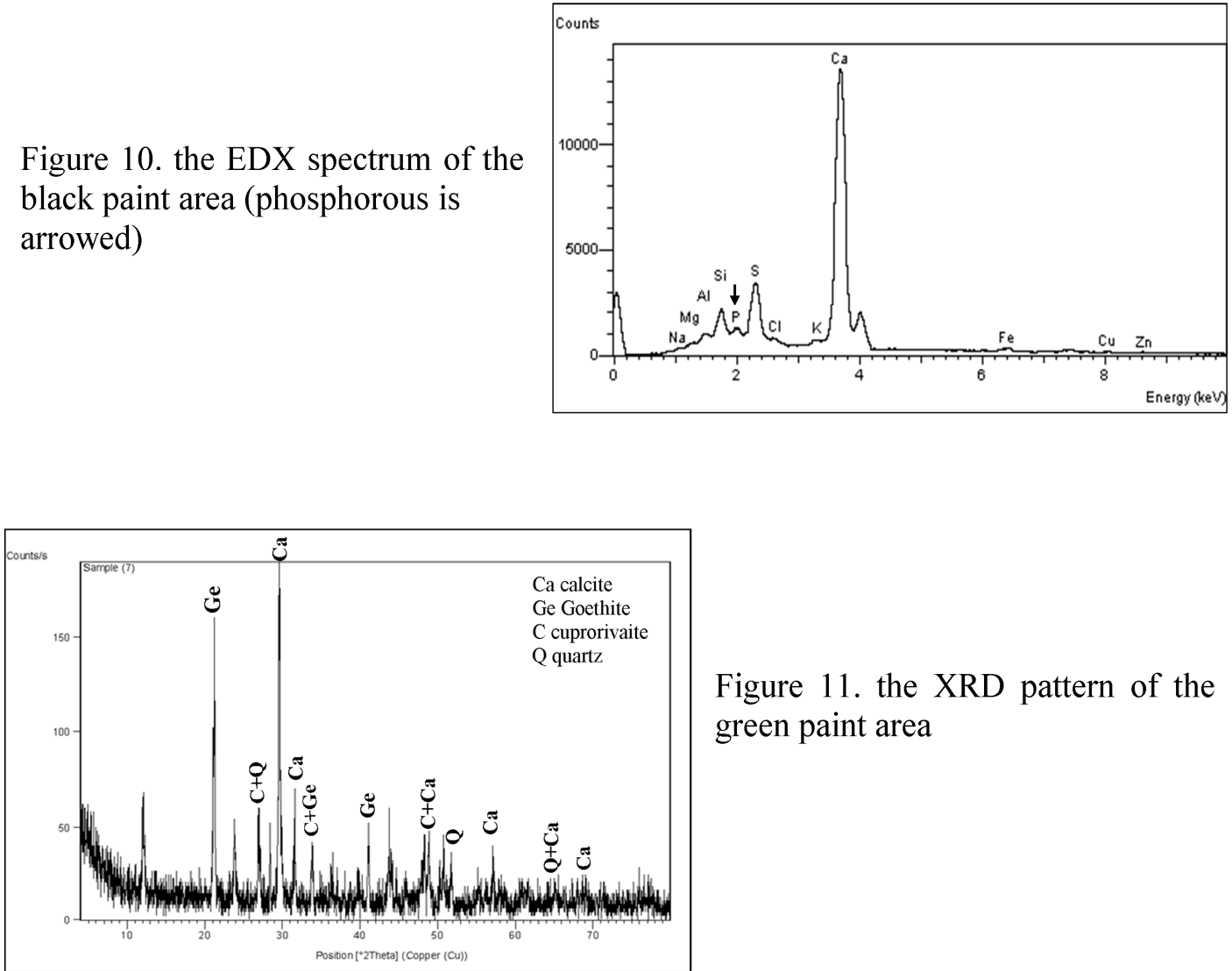

Figure 11. the XRD pattern of the green paint area 